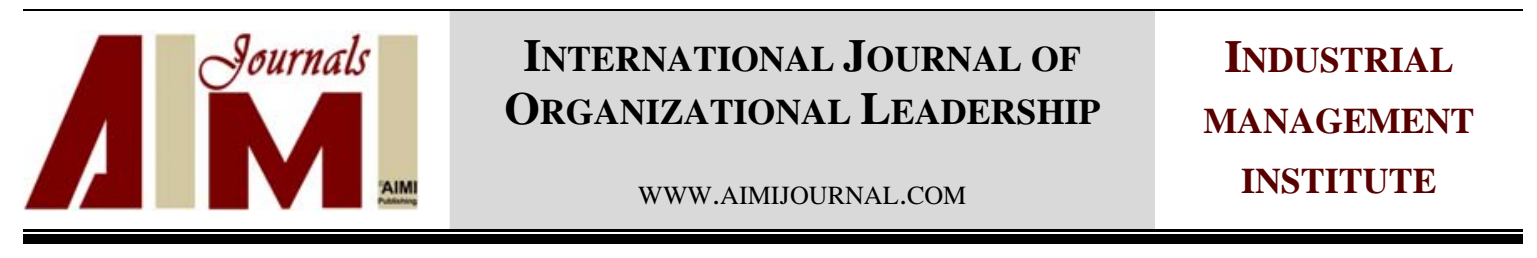

\title{
On the applicability of analysis of internal and external factors: A case study of Imam Khomeini Relief Foundation in Ardabil
}

\author{
Houshang Sharifi Namin
}

Department of Management, Islamic Azad University, Ardabil Branch, Ardabil, Iran

\begin{abstract}
Keywords:

SWOT Analysis, Environmental Factors, Charitable Organizations, Strategies Attractiveness, Imam Khomeini Relief Foundation

Correspondence:

Recognition and prioritization of environmental factors affecting the performance of organizations is one of the most important steps in developing long-term plans and organizational strategies. The present study investigates the current status of head office of Ardabil Imam Khomeini Relief Foundation through analyzing internal and external environmental factors. To this end, a sequential mixed method design was used for collecting, analyzing, and interpreting research question. Sixty-eight employees participated in the study. This study was carried out through a survey method using research-made questionnaire and interview as the main instruments. The results demonstrated that Ardabil Imam Khomeini Relief Foundation had some strengths and weaknesses regarding internal and external environmental factors and this organization appeared to have relatively good position considering organization's internal factors which were supposed to affect it. The findings of the study showed that Ardabil Imam Khomeini Relief Foundation can overcome and neutralize some of its organizational threats and weaknesses using the current organizational opportunities and strengths and applying strategic planning.
\end{abstract} Sharifinamin@gmail.com

(C)AIMI Journals

\section{Introduction}

Strategic planning is a process undertaken by an organization to determine and establish long-term directions and formulate and implement strategies to accomplish long-term objectives while taking into account relevant internal and external environmental variables 
(Hax \& Majluf, 1990). During three decades of empirical research, strategic planning has been proven to be an essential prerequisite for successful organizations such as public agencies, departments, major organizational divisions, non-profit organizations, and purposedriven interorganizational networks (Bryson, 2004; Burby, 2003; Innes \& Booher, 2010; Nelson \& French, 2002; Vilà \& Canales, 2008). Although the economic benefits of planning have received much attention in the general management literature (e.g., Armstrong, 1982; Kudla, 1980; Miller \& Cardinal, 1994; Pearce, Freeman, \& Robinson, 1987; Rhyne, 1986; Shrader, Taylor, \& Dalton, 1984), the strategic planning-performance relationship appears to have been largely overlooked in the management literature (Athiyaman, 1995; Ingram, 1995; Phillips, 1998; Phillips \& Moutinho, 1998, 2000). Strategic planning is an organization's process of defining its strategy or direction and making decisions on allocating its resources to pursue this strategy (Shariatmadari, Sarfaraz, Hedayat, \& Vadoudi, 2013). In other words, strategic planning is having an understanding where you are as an organization; setting a vision for where you want to be; and developing strategic alternatives how to achieve that vision (Krajewski \& Ritzman, 1996). Strategic planning is concerned with formulating strategy (Bryson, Crosby, \& Bryson, 2009; Poister, 2010). A strategy as an emergent phenomenon is the common thread or underlying logic that holds a business together (Jarratt \& Stiles, 2010). It determines the structure of the organization, the activities employed, and the economic performance (Farhoodi, Gharakhlou, Ghadami, \& Panahandeh Khah, 2009). The concept of strategy is perceived as a pattern in a stream of past or intended decisions that involve internal and/or external alignment which affects organizational performance (Hambrick, 1983). The main objective of strategic planning is effective implementation of the law in order to determine its optimal position and intended route. Although different organizations and institutions use different terminologies for this concept, all of them should plan to achieve success and progress (Spee \& Jarzabkowski, 2011; Tassabehji \& Isherwood, 2014). For this aim, charitable organizations and non-governmental organizations (NGOs) in all over the world should determine their present status with a strategic perspective to increase efficacy, effectiveness, and satisfaction in the target society and determine the best way to achieve their objectives in the operational programs framework related to their duties based on their strengths, weaknesses, opportunities, and threats (SWOT) to answer the needs of society (Green \& Webb, 1997; Helms, Scott, \& Thornton, 2012; Wong, 2007). In this regard, such organizations seek to achieve goals endorsed by those with altruistic values (Bekkers \& Bowman, 2009). Strategic planning provides an answer for the basic weaknesses 
of comprehensive planning to fulfill the needs of today's cities and guide their growth and future development which are used to categorize significant environmental factors both internal and external to the organization (Grant, 2003; Pickton \& Wright, 1998; Rigby, 1999; $\mathrm{Wu}, 2007)$. In spite of the importance of strategic planning, most organizations do not realize that how this vital element can enable the organizations to achieve their goals and sometimes even it is considered as a luxury and costly concept by some managers (Shariatmadari, Sarfaraz, Hedayat, \& Vadoudi, 2013). Some researchers stated that strategic planning is representative of creativity and innovation of management (Brews \& Hunt, 1999; Dibrell, Craig, \& Neubaum, 2014; Grant, 2003; Rudd, Greenley, Beatson, \& Lings, 2008). Among these organizations in Iran, Imam Khomeini Relief Foundation has a particular importance because of factors such as decreasing social damages, developing and improving servicing, and promoting adequacy, desirability, and universality in the target society. The managers of charitable organizations are required to use their own abilities and creativities in order to adapt themselves to the dynamic and complex environment. The key component of such kind of planning is providing information about strengths and weaknesses as internal environmental factors and opportunities and threats as external environmental factors to the organization (Gorener, Toker, \& Ulucay, 2012). Strategic planning lends a long-term perspective to management and brings a promising and desirable future for Imam Khomeini Relief Foundation. Without strategic planning and considering external and internal environmental factors, planning loses its effectiveness. Before beginning to plan an organization's future, its current position should be specified. Good performance within an organization is the result of direct interaction of business management with its internal and external environment (Gorener, Toker, \& Ulucay, 2012). In addition, fundamental decisions for improving organizational performance should be taken into account. This study reports on an investigation into the effect of external and internal factors on the performance of Imam Khomeini Relief Foundation’s employees in Ardabil, Iran.

\section{The Literature Review}

Precisely speaking, strategic planning is the process of determining organizational goals and objectives and making operational and executive decisions for achieving the goals. It usually starts with strategic objectives. Objectives indicate what management expects to accomplish, whereas planning sets forth how, when, where, and by whom the objectives will be attained. Strategic objectives give rise to strategic planning maturities (Ackoff, 1970; Ansoff, 1991; 
Harrison, 1995). Strategic planning, on the other hand, is long-term, analytical as well as visionary, and therefore calls for a different way of thinking than has been required in the past in developing organizations development plans (Davies, 2010; Mbugua \& Rarieya, 2013; Quong \& Walker, 2010). An effective strategic planning requires top managers' active roles in defining the strategic direction of the organization and creating an environment that recognizes strategic planning as a tool of strategic management (Ugboro, Obeng, \& Spann, 2011).

\section{SWOT Analysis}

The mechanisms which are used to evaluate internal and external factors are called assessment of the internal and external environment including a basic SWOT form that can provide an accurate and reliable measure for assessing an organization (Clark, 2011; Forest, 2013). Assessment of the internal and external environment is considered as a management tool which is used in strategic planning and problem solving for setting future priorities and directions. The data that is collected primarily leads to identifying key strategic issues and goals. The main purpose of strategic analysis of external and internal factors is maximizing strengths, minimizing weaknesses, seizing opportunities, and neutralizing threats (David, 2010). The importance of SWOT analysis is its internal scrutiny of the organization's capabilities, followed by environmental scanning to identify appropriate opportunities and threats. The merit of SWOT as the leading tool for strategic analysis lies in its simplicity and clarity (Pickton \& Wright, 1998). Furthermore, SWOT analysis is an established planning tool for devising strategy and supporting the decision makers in focusing on key issues (Arslan \& Er, 2008; Diamantopoulou \& Voudouris, 2008; Lee, Huang, \& Teng, 2009; Markovska, Taseska, \& Pop-Jordanov, 2009; Paliwal, 2006; Yuksel \& Dagdeviren, 2007). In fact, SWOT analysis provides a framework for taking advantage of opportunities as well as mitigating weaknesses and reducing threats that the area faces (Rauch, 2007; Shinno, Yoshioka, Marpaung, \& Hachiga, 2006; Terrados, Almonacid, \& Hontoria, 2007). It can generally help depict a strategic organizational situation and identify what information is needed and what decisions are to be made on personal and organization levels (Balamuralikrishna \& Dugger, 1995). This tool helps look at the organization's current

performance (strengths and weaknesses) and the organization's future (opportunities and threats) by accounting for the factors that exist in the external environment. SWOT is a powerful and sometimes highly successful technique that can be applied to individuals, 
groups, teams, organizations, or even plans (Chermack \& Kasshanna, 2007; David, 1997). These techniques also help planners and policy-makers to explore project strengths, minimize weaknesses, and take the greatest possible return of available opportunities (Arslan \& Er, 2008; Paliwal, 2006). Assessment of internal environmental factors enables managers to improve their service by identifying objectively and carefully their competitors' weaknesses and strengths. Having analyzed outcome information, managers can benefit the opportunities for investment and reduce the negative effects of probable threats. Identifying and evaluating the strengths and weaknesses enables an organization to select the best suited strategies to the organization dealing with uncertain and dynamic external environmental forces (Bryson, 2004). What is considered significant in the present analysis is assessing internal environmental factors and assessing external environmental factors with regard to strategic aspects. SWOT analysis is one of the most effective approaches used for analyzing strategic management policy of an organization (Coman \& Ronen, 2009; Houben, Linie, \& Vanhoof, 1999; Shinno, Yoshioka, Marpaung, \& Hachiga, 2006). In other words, the SWOTs analyses which are directly related to the strategic objectives of the charitable organization can only take into account. The relationship between different kinds of variables for describing the current status of organization and the effect of these environmental variables on providing a proper perspective and performing the functions should be determined in advance. The

purpose of the analysis of external opportunities and threats is to assess whether an enterprise can seize opportunities and avoid threats when facing an uncontrollable external environment, such as fluctuating prices and political destabilization (Hai \& Tsou, 2009). This initial assessment makes a clear distinction between internal and external environmental factors. In this assessment, environmental analysis should be examined at two different levels including external environment such as workforce, suppliers, social, economical, political, legal, cultural, international, competitive, and technological factors and internal environment such as human and financial resources, organizational structure, and processes and IT systems.

\section{Research Question}

This study specifically aimed to answer the following question:

Which strategies are considered to be suitable with respect to analysis of both internal and external factors in Ardabil Imam Khomeini Relief Foundation? 


\section{Method}

The participants of this study were 68 employees of the head office of Imam Khomeini Relief Foundation in Ardabil, Iran. For the purpose of this study, both qualitative and quantitative methods were used. The data collected through conducting focused group discussion (FGD) and interview and completing two researcher-made questionnaires. The questionnaires distributed in two phases and the interview was semi-structured. The data obtained in the first phase was analyzed using FGD following Adel and Momeni (2002). The resulting data from the questionnaire was analyzed through running descriptive statistics and SWOT analysis. In the first questionnaire, the participants were asked to list and rank SWOTs that the Ardabil Imam Khomeini Relief Foundation had been faced. The organization's internal environment, in terms of strengths and weaknesses, were financial and human resources, organizational structure, and processes and IT systems and its external environment in terms of opportunities and threats were social, cultural, economical, political, legal, international, competitive technological factors, suppliers, and workforce. The questionnaire enjoyed acceptable levels of validity and reliability. It measured each item's importance in charitable organization by means of a four-point Likert scale ranging from strongly disagree (1 point) to strongly agree (4 points). In the second phase, the second questionnaire was distributed to the participants to identify and assess external and internal factors in the organization. In this questionnaire, first, the most important factors were categorized and prioritized, then internal factor evaluation (IFE) and external factor evaluation (EFE) matrixes were formed. At the next step, the relative importance of each factor (1=very important, $0=$ not important) and the ranking of each one from 1 to 4 was determined. To calculate the final score of each factor, each factor's relative importance coefficient was multiplied by its rank and then the final scores were estimated. The general strategies of internal and external factors were estimated using SWOT framework and then Ardabil Imam Khomeini Relief Foundation's strategies were identified by using these general strategies. In addition, based on external and internal factors, the quantitative strategic planning matrix (QSPM) and coefficient of attractiveness for each factor were determined from 0 to 100. To determine the amount of attractiveness and priority of strategies, each factor's relative importance coefficient was multiplied by strategies attractiveness coefficient. Based on the obtained scores, attractiveness matrix and strategies prioritization process of this organization toward internal and external factors were identified. This qualitative method ensured high levels of reliability and accuracy of the data. The 
researcher omitted or added some options to the questionnaire based on the interviewees' instructive feedback and opinions.

\section{Results}

The results obtained from the questionnaires and interview revealed weaknesses, strengths, threats, and opportunities of Ardabil Imam Khomeini Relief Foundation. The strengths were approving and following the constitution, scattering service centers all around the province, accepting the supreme, i.e., leadership of the country, seeking the public's help, and enjoying charitable activities of donors, institutions, and organizations, accumulating capitals, loans, and possessions, enhancing public trust, applying the rules by experts and managers, providing framework or foundation for developing IT, and enjoying public credits. On the other hand, weaknesses were limited to a number of male and female social workers and specialists in proportion to organization's needs, the absence of mental engineering in public view, the lack of improved services, underdevelopment of organizational memory, insufficient credit for doing applied research, insufficient training of knowledgeable and long-sighted managers, the mismatch of organizational structure with job description and duties, and receiving delayed construction or development credits. A SWOT analysis identified opportunities and threats to assist Ardabil Imam Khomeini Relief Foundation in making its strategic plans and decisions. The opportunities were obtaining profit value of public and non-profit charities, designing suitable background for setting work process optimization, benefiting from new information and communication technologies, having religious beliefs, public trust, and human emotions; having increasing faith in God, having considerable tourism potential for public participation development, the effect of farming and ranching operations on job creation potential, having cultural and social welfare services background, and making use of loan companies and bank facilities. Threats were any external development that might hinder or prevent the business from achieving its objectives. The identified threats for this organization were the size of holdhouses or families below the poverty line, high unemployment rate, unrealistic approach of society towards the nature and the activities of charitable organization, lack of interest in using modern technologies and major industries for developing public participation, lack of membership in the supreme council and related organizations, increasing social damages and disorders, the low level of literacy, and increasing rate of divorce and addiction in province. Tables 1 and 2 present evaluation matrices of internal and external factors respectively. As Table 1 displays, the 
relative importance coefficient results of internal factors in strengths section including approving the constitution, accepting Velayat-e-faqih, and seeking public help and factors like limited number of social workers and specialists and absence of mental engineering in public view from weaknesses section showed higher scores (6\%) and ranks (3).

Table 1

Internal Factors Evaluation Matrix in Imam Khomeini Relief Foundation in Ardabil

\begin{tabular}{|c|c|c|c|c|}
\hline & Internal Factors & $\begin{array}{c}\text { Relative Importance } \\
\text { Coefficient }\end{array}$ & Rank & Score \\
\hline \multirow{7}{*}{ 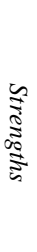 } & Approving the constitution & $6 \%$ & 3 & 0.18 \\
\hline & Scattering service centers & $5 \%$ & 2 & 0.10 \\
\hline & Accepting Velayat-e-faqih & $6 \%$ & 3 & 0.18 \\
\hline & Seeking public help & $6 \%$ & 3 & 0.18 \\
\hline & Enjoying donors', and organizations' charitable activities & $5 \%$ & 3 & 0.15 \\
\hline & Accumulating capital, loan, and possession & $5 \%$ & 3 & 0.15 \\
\hline & Enhancing public trust & $5 \%$ & 3 & 0.15 \\
\hline \multirow{14}{*}{ 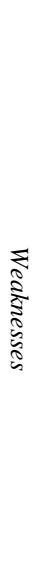 } & Applying the rules by experts and managers & $4 \%$ & 2 & 0.08 \\
\hline & Providing a foundation for developing IT & $5 \%$ & 2 & 0.10 \\
\hline & Having public credit & $4 \%$ & 2 & 0.08 \\
\hline & Limited number of social workers and specialists & $6 \%$ & 3 & 0.18 \\
\hline & Absence of mental engineering in public view & $6 \%$ & 3 & 0.18 \\
\hline & Lack of improved services & $5 \%$ & 2 & 0.10 \\
\hline & Underdevelopment of organizational memory & $5 \%$ & 2 & 0.10 \\
\hline & Insufficient credit for doing applied research & $5 \%$ & 2 & 0.10 \\
\hline & Insufficient training of knowledgeable managers & $5 \%$ & 2 & 0.10 \\
\hline & Mismatch of organizational structure with job description & $4 \%$ & 2 & 0.08 \\
\hline & Delayed receive of construction credit & $4 \%$ & 2 & 0.08 \\
\hline & Lack of more precise job description & $4 \%$ & 2 & 0.08 \\
\hline & Inadequacy of servicing credits & $5 \%$ & 2 & 0.10 \\
\hline & Total & $100 \%$ & 48 & 2.45 \\
\hline
\end{tabular}

Table2

External Factors Evaluation Matrix in Imam Khomeini Relief Foundation in Ardabil

\begin{tabular}{lccc}
\hline External Factors & $\begin{array}{c}\text { Relative Importance } \\
\text { Coefficient }\end{array}$ & Rank & Score \\
\hline Obtaining profit value of public and non-profit charities & $6 \%$ & 3 & 0.18 \\
Designing suitable background for setting work process optimization & $5 \%$ & 2 & 0.08 \\
Benefitting from new information and communication technologies & $6 \%$ & 3 & 0.18 \\
The authorities and people's beliefs, public trust, and human emotions & $6 \%$ & 3 & 0.18 \\
Having an increasing faith in God & $5 \%$ & 2 & 0.10 \\
Having considerable tourism potential for public participation development & $5 \%$ & 3 & 0.15 \\
Affecting farming and ranching operations on job creation potential & $5 \%$ & 3 & 0.15 \\
Having cultural and social welfare services background & $4 \%$ & 2 & 0.10 \\
Providing public assemblies and religious groups & $5 \%$ & 2 & 0.08 \\
Making use of loan companies and bank facilities & $4 \%$ & 2 & 0.08 \\
The large number of families below the poverty line & & 3 & 0.18 \\
High unemployment rate & $6 \%$ & 4 & 0.24 \\
Unrealistic approach of society towards the nature and activities of & $6 \%$ & 3 & 0.18 \\
charitable organization & $5 \%$ & & \\
Lack of interest in using modern technologies & & 2 & 0.08 \\
Lack of major industries in province & $5 \%$ & 3 & 0.18 \\
Having low industrial skills & $5 \%$ & 3 & 0.15 \\
Lack of membership in the supreme council and related & $5 \%$ & 2 & 0.06
\end{tabular}


Organizations

Increasing social damages and disorders

Low level of literacy

Increasing rate of divorce and addiction

Total

$\begin{array}{ccc} & 3 & 0.15 \\ 4 \% & & \\ 4 \% & 2 & 0.08 \\ 5 \% & 3 & 0.15 \\ 100 \% & 53 & 2.73\end{array}$

As Table 2 shows, the relative importance coefficients of internal factors for the opportunities section including obtaining profit value of public and non-profit charities, benefiting from new information and communication technologies, and the authorities and people's beliefs, public trust, and human emotions were 6 per cent which demonstrated higher scores than other factors in this section. The relative importance coefficients of internal factors consisting of large number of families below the poverty line and high unemployment rate in threats section tended to be 6 per cent. Table 3 shows the strategies' attractiveness matrix of internal and external factors. Regarding to environmental factors, it demonstrates the priority of strategies for Ardabil Imam Khomeini Relief Foundation.

Table 3

Strategies Attractiveness Matrix Regarding External and Internal Factors

\begin{tabular}{|c|c|c|c|}
\hline Strategies & $\begin{array}{l}\text { Attractiveness of } \\
\text { External Factors } \\
\text { Score }\end{array}$ & $\begin{array}{l}\text { Attractiveness of } \\
\text { Internal Factors } \\
\text { Score }\end{array}$ & Average \\
\hline Developing public and specialized consulting services & 565 & 510 & 538 \\
\hline Promoting family training programs in social, health, and cultural dimensions & 560 & 500 & 530 \\
\hline Distributing Islamic culture to prevent social damages and disorders & 528 & 520 & 524 \\
\hline $\begin{array}{l}\text { Using educational organizations' potentials considering promoting literacy in } \\
\text { target society }\end{array}$ & 550 & 490 & 520 \\
\hline Doing applied researches & 529 & 500 & 515 \\
\hline Extending unites of servicing to eliminate poverty in the target society & 514 & 510 & 512 \\
\hline Empowering the target society by providing employment skills & 520 & 500 & 510 \\
\hline Providing social insurance in target society & 530 & 490 & 510 \\
\hline Founding and enriching charitable organizations & 479 & 530 & 505 \\
\hline Providing the mechanisms of improving motivation & 498 & 510 & 504 \\
\hline Managing servicing systems comprehensively & 502 & 500 & 501 \\
\hline $\begin{array}{l}\text { Enlightening public view and running continuous survey based on scientific } \\
\text { methods }\end{array}$ & 470 & 520 & 495 \\
\hline Applying for membership of the professional councils & 480 & 510 & 495 \\
\hline Adopting subsidies to the target household groups by separating income deciles & 510 & 480 & 495 \\
\hline Promoting the culture of doing charitable activities & 470 & 520 & 495 \\
\hline Specializing public helps & 462 & 510 & 486 \\
\hline Decentralizing management of public funds & 477 & 470 & 474 \\
\hline Using modern technologies to enhance public participation & 443 & 490 & 467 \\
\hline $\begin{array}{l}\text { Finding the problems of organizational processes and establishing quality } \\
\text { management system }\end{array}$ & 450 & 480 & 465 \\
\hline Using public funds to reduce the rate of unemployment in the target society & 510 & 400 & 455 \\
\hline
\end{tabular}

\section{Discussion}

The findings of the study revealed that Ardabil Imam Khomeini Relief Foundation was in a fairly good position. This indicated that Ardabil Imam Khomeini Relief Foundation's 
strategic internal factors had more strengths than weaknesses and regarding to external factors this organization had more threats than opportunities. In fact, this organization can use these strengths to overcome identified external threats; for instance, in most cases, Ardabil Imam Khomeini Relief Foundation can overcome the environmental threats and weaknesses using strengths such as spreading servicing centers. One of current threats in the society is enhancing social disorders and damages which this organization can overcome them in target societies by implementing programs such as developing social skills training, providing consultation and guidance services, and developing legal services and assistance. Besides, one other threat of society is large number of families below the poverty line. Ardabil Imam Khomeini Relief Foundation applied some programs such as housing, providing assisted living for the first income docile, increasing and providing necessary medical and health services for needy people in the bottom two income deciles, improving training and educational service for both university and school students, recruiting talented graduates, and providing social insurance for workers and families in target society. Regarding the fact that Ardabil has not any major industries, it can benefit from its farming and ranching products and handicrafts. Therefore, it can create a lot of jobs in the related fields and find local markets and cooperative centers in the province to obtain the warranty service of their products.

The results also revealed that the dominant strategy in Ardabil Imam Khomeini Relief Foundation was a conservative strategy. Identifying the organization's current status regarding the external and internal factors and the main strategy in Ardabil, some strategies for improving the present statues of this organization were proposed. One of these strategies is to empower the target society by providing employment skills. The second strategy is to apply for membership of the professional councils. Public enlightenment and running continuous survey based on scientific methods are other strategies that should be taken into account. Furthermore, they should try to extend some servicing unites to eliminate poverty in the target society and use educational organizations' potentials to promote literacy in target society. They should also try to distribute Islamic culture throughout the target society to prevent social disorders and damages. They can provide the mechanisms of improving motivation, manage servicing systems comprehensively, and decentralize management of public funds through founding and enriching charitable organizations. This organization can use public funds to reduce the rate of unemployment in the target society. Specifying public help, using modern technologies to enhance public participation, promoting family training 
programs in social, cultural, and health dimensions, adopting subsidies to the target household groups by separating income deciles are other strategies that this organization should pay more attention to them. In addition, the organization should find the problems of organizational processes and establish quality management system. Developing comprehensive public and specialized consulting services, providing social insurance companies in target society, doing applied research, and promoting the culture of doing charitable activities are other factors that should be considered. Implementing the determined strategies and internal and external factors, the strategic planning matrix is employed to prioritize organizational strategies regarding external and internal factors.

\section{Conclusion}

The present study set out to investigate the influence of analyzing external and internal environmental factors on the performance of Imam Khomeini Relief Foundation's employees in Ardabil and prioritizing their strategies. Results indicated that Ardabil Imam Khomeini Relief Foundation's strategic internal factors had more strengths than weaknesses and more threats than opportunities regarding to external factors and conservative strategy was the dominant strategy in this organization. Results of both the qualitative and quantitative studies in this research supported the prominent role of analyzing environmental factors on promoting organizational performance and selecting appropriate strategies. The present study is not free from limitations. The very first limitation of the study relates to using only Ardabil Imam Khomeini Relief Foundation's employees and excluding other charitable organizations and private funds. Second, this analysis can be expanded to incorporate additional internal and external firm factors. In the future, an exploration of the dynamic relationships between these variables and those adopted in our study will certainly add to our understanding of how to promote organizational performance. Third, the number of participants in this study was relatively small so the findings for this study can hardly be generalized to the whole population of different charitable organizations in Iran. Fourth, this study used two researcher-made questionnaires and an interview to elicit information from employees. The use of other qualitative method such as observation could have increased the validity of data. Armed with the data obtained from questionnaire and interview, it can be suggested that Ardabil Imam Khomeini Relief Foundation need to codify its annually operational programs and implement and assess them regularly using balanced scorecard (BSC) model (Kaplan \& Norton, 2006). In order to strengthen and back up the findings and conclusions in this study, 


\section{it is essential to implement further research in analyzing external and internal environmental factors affecting organizational performance.}

\section{References}

Ackoff, R. L. (1970). Concept of strategic planning. London: Wiley-Interscience.

Adel, A., \& Momeni, M. (2002). Statistics and its application in management. Tehran: SAMT Publication.

Ansoff, I. H. (1991). A critique of Henry Mintzberg's the design school: Reconsidering the basic premises of strategic management. Strategic Management Journal, 12(6), 449-461.

Armstrong, J. S. (1982). The value of formal planning for strategic decisions: Review of empirical research. Strategic Management Journal, 3(3), 197-211.

Arslan, O., \& Er, I. D. (2008). A SWOT analysis for successful bridge team organization and safer marine operations. Process Safety Progress, 27(1), 21-28.

Athiyaman, A. (1995). The interface of tourism and strategy research: An analysis. Tourism Management, 16(6), 447- 453.

Balamuralikrishna, R., \& Dugger, J. (1995). SWOT analysis: A management tool for initiating new programs in vocational schools. Journal of Vocational \& Technical Education, 12(1), 36-41.

Bekkers, R., \& Bowman, W. (2009). The relationship between confidence in charitable organizations and volunteering revisited. Nonprofit \& Voluntary Sector Quarterly, 38(5), 884-896.

Boyson, J. M. (2004). Strategic planning for public and nonprofit organizations: A guide to strengthening and sustaining organizational achievement ( $3^{\text {rd }}$ ed.). San Francisco: Jossey- Bass.

Brews, P. J., \& Hunt, M. R. (1999). Learning to plan and planning to learn: Resolving the planning school/learning school debate. Strategic Management Journal, 20(10), 889-913.

Bryson, J. M. (2004). Strategic planning for public and nonprofit organizations ( $3^{\text {rd }}$ ed.). San Francisco: Jossey-Bass.

Bryson, J. M., Crosby, B. C., \& Bryson, J. K. (2009). Understanding strategic planning and the formulation and implementation of strategic plans as a way of knowing: The contributions of actor-network theory. International Public Management Journal, 12(2), 172-207.

Burby, R. J. (2003). Making plans that matter: Citizen involvement and government action. Journal of the American Planning Association, 69(1), 33-49.

Chermack, T. J., \& Kasshanna, B. K. (2007). The use and misuse of SWOT analysis and implications for HRD professionals. Human Resource Development International, 10(4), 383-399.

Clark, A. (2011). Educators versus entrepreneurs: Traits and bias in the teaching of SWOT. Journal of Further \& Higher Education, 35(2), 287-298.

Coman, A., \& Ronen, B. (2009). Focused SWOT: Diagnosing critical strengths and weaknesses. International Journal of Production Research, 47(20), 5677-5689.

David, F. (1997). Strategic management ( $6^{\text {th }}$ ed.). Upper Saddle River, NJ: Prentice Hall.

David, F. R. (2010). Strategic management. England: Prentice Hall.

Davies, B., \& Davies, B. J. (2010). The nature and dimensions of strategic leadership. International Studies in Educational Administration, 38(1), 1-21.

Diamantopoulou, P., \& Voudouris, K. (2008). Optimization of water resources management using SWOT analysis: The case of Zakynthos Island, Ionian Sea, Greece. Environmental Geology, 54(1), 197-211.

Dibrell, C., Craig, J. B., \& Neubaum, D. O. (2014). Linking the formal strategic planning process, planning flexibility, and innovativeness to firm performance. Journal of Business Research, 67(9), 2000-2007.

Farhoodi, R., Gharakhlou, M., Ghadami, M., \& Panahandeh Khah, M. (2009). A critique of the prevailing comprehensive urban planning paradigm in Iran: The need for strategic planning. Planning Theory, 8(4), 335-361.

Forest, J. J. (2013). Management discipline: Defining a process safety strategy. Process Safety Progress, 33(2), 162-165.

Gorener, A., Toker, K., \& Ulucay, K. (2012). Application of combined SWOT and AHP: A case study for a manufacturing firm. Procedia - Social \& Behavioral Sciences, 58(1), 1525-1534.

Grant, R. M. (2003). Strategic planning in a turbulent environment: Evidence from the oil majors. Strategic Management Journal, 24(6), 491-518. 
Green, C. L., \& Webb, D. J. (1997). Factors influencing monetary donations to charitable organizations. Journal of Nonprofit \& Public Sector Marketing, 5(3), 19-40.

Hai, H. L., \& Tsou, M. C. (2009). Strategic development of Shih Chien university Kaohsiung campus in Taiwan by a quantifiable SWOT analysis. Journal of Information \& Optimization Science, 30(1), 87-99.

Hambrick, D. C. (1983). High profit strategies in mature capital goods industries: A contingency approach. Academy of Management Journal, 26(4), 687-707.

Harrison, E. F. (1995). Strategic planning maturities. Management Decision, 33(2), 48-55.

Hax, A. C., \& Majluf, N. S. (1990). The strategic concept and process: A pragmatic approach. Englewood Cliffs, NJ: Prentice Hall.

Helms, S. E., Scott, B. L., \& Thornton, J. P. (2012). Choosing to give more: Experimental evidence on restricted gifts and charitable behavior. Applied Economics Letters, 19(8), 745-748.

Houben, G., Linie, K., \& Vanhoof, K. (1999). A knowledge-based SWOT-analysis system as an instrument for strategic planning in small and medium sized enterprises. Decision Support Systems, 26(2), 125-135.

Ingram, H. (1995). Hospitality and tourism: International industries experiencing common problems. International Journal of Contemporary Hospitality Management, 7(7), 44-54.

Innes, J. E., \& Booher, D. E. (2010). Planning with complexity: An introduction to collaborative rationality for public policy. New York: Routledge.

Jarratt, D., \& Stiles, D. (2010). How are methodologies and tools framing managers' strategizing practice in competitive strategy development? British Journal of Management, 21(1), 28-43.

Kaplan, R. S., \& Norton, D. P. (2006). Alignment: Using the balanced scorecard (BSC) to create corporate synergies. Boston: HBS Press.

Krajewski, L. J., \& Ritzman, L. P. (1996). Operations management strategy and analysis (4 ${ }^{\text {th }}$ ed.). Massachusetts: AddisonWesley Publishing.

Kudla, R. J. (1980). The effects of strategic planning on common stock returns. Academy of Management Journal, 23(1), 520.

Lee, K. L., Huang, W. C., \& Teng, J.Y. (2009). Locating the competitive relation of a global logistics hub using quantitative SWOT analytical method. Quality \& Quantity, 43(1), 8-107.

Markovska, N., Taseska, V., \& Pop-Jordanov, J. (2009). SWOT analyses of the national energy sector for sustainable energy development. Energy, 34(6), 752-756.

Mbugua, F., \& Rarieya, J. F. A. (2013). Collaborative strategic planning: Myth or reality? Educational Management Administration \& Leadership, 42(1), 99-111.

Miller, C. C., \& Cardinal, L. B. (1994). Strategic planning and firm performance: A synthesis of more than two decades. Academy of Management Journal, 37(6), 1649-1665.

Nelson, A. C., \& French, S. P. (2002). Plan quality and mitigating damage from natural disasters. Journal of the American Planning Association, 68(2), 194-208.

Paliwal, R. (2006). EIA practice in India and its evaluation using SWOT analysis. Environmental Impact Assessment Review, 26(5), 492-510.

Pearce, J., Freeman, E., \& Robinson, R. (1987). The tenuous link between formal strategic planning and financial performance. Academy of Management Review, 12(4), 658-675.

Phillips, P. A., (1998). Strategic planning systems in hospitality and tourism. Oxford: CAB International.

Phillips, P. A., \& Moutinho, L. (1998). The marketing planning index (MPI): A tool for measuring marketing planning effectiveness. Journal of Travel \& Tourism Marketing, 17(3), 41-60.

Philips, P. A., \& Moutinho, L. (2000).The strategic planning index: A tool for measuring strategic planning effectiveness. Journal of Travel Research, 38(4), 369-379.

Pickton, D. W., \& Wright, S. (1998).What's SWOT in strategic analysis? Strategic Change, 7(2), 101-109.

Poister, T. H. (2010). The future of strategic planning in the public sector: Linking strategic management and performance. Public Administration Review, 70(1), 246-254.

Quong, T., \& Walker, A. (2010). Seven principles of strategic leadership. International Studies in Educational Administration, 38(1), 22-34.

Rauch, P. (2007). SWOT analyses and SWOT strategy formulation for forest owner cooperation in Austria. European Journal of Forest Research, 126(3), 413-420. 
Rhyne, L. C. (1986). The relationship of strategic planning to company performance. Strategic Management Journal, 7(5), 423- 436.

Rigby, D. (1999). Management tools and techniques. Boston, MA: Bain \& Company.

Rudd, J. M., Greenley, G. E., Beatson, A. T., \& Lings, I. N. (2008). Strategic planning and performance: Extending the debate. Journal of Business Research, 61(2), 99-108.

Shariatmadari, M., Sarfaraz, A. H., Hedayat, P., \& Vadoudi, K. (2013). Using SWOT analysis and SEM to prioritize strategies in foreign exchange market in Iran. Procedia-Social \& Behavioral Sciences, 99, 886-892.

Shinno, H., Yoshioka, H., Marpaung, S., \& Hachiga, S. (2006). Quantitative SWOT analysis on global competitiveness of machine tool industry. Journal of Engineering Design, 17(3), 251-258.

Shrader, C., Taylor, L., \& Dalton, D. (1984). Strategic planning and organizational performance: A critical appraisal. Journal of Management, 10(2), 149-171.

Spee, A. P., \& Jarzabkowski, P. (2011). Strategic planning as communicative process. Organization Studies, 32(9), 12171245.

Terrados, J., Almonacid, G., \& Hontoria, L. (2007). Regional energy planning through SWOT analysis and strategic planning tools: Impact on renewable development. Renewable \& Sustainable Energy Reviews, 11(6), 1275-1287.

Tassabehji, R., \& Isherwood, A. (2014). Management use of strategic tools for innovating during turbulent times. Strategic Change, 23(1/2), 63-80.

Ugboro, I. O., Obeng, k., \& Spann, O. (2011). Strategic planning as an effective tool of strategic management in public sector organizations: Evidence from public transit organizations. Administration \& Society, 43(1), 87-123.

Vilà, J., \& Canales, J. I. (2008). Can strategic planning make strategy more relevant and build commitment over times? The case of RACC. Long Range Planning, 41(3), 273-290.

Wong, H. K. (2007). The foundations for charitable organization and giving. Asia Pacific Journal of Social Work \& Development, 17(1), 35-52.

Wu, F. (2007). Reorientation of the city plan: Strategic planning and design competition in China. Geo forum, 38(2), 379392.

Yuksel, I., \& Dagdeviren, M. (2007). Using the analytic network process (ANP) in a SWOT analysis: A case study for a textile firm. Information Sciences, 177(16), 3364-3382. 